\title{
Experimental and Numerical Analysis of Geosynthetic-Reinforced Floating Granular Piles in Soft Clays
}

\author{
$\operatorname{Murtaza}_{\operatorname{Hasan}^{1}}$ - N. K. Samadhiya ${ }^{1}$
}

Received: 20 May 2016/Accepted: 27 June 2016/Published online: 11 July 2016

(c) Springer International Publishing Switzerland 2016

\begin{abstract}
The installation of reinforced granular piles is a commonly adopted technique to improve load carrying capacity and reduce settlements in very soft clayey soils. This paper presents results of a series of laboratory model tests and numerical analysis carried on geosynthetic reinforced granular pile under short term loading. Unit cell concept has been adopted. Laboratory model tests were conducted on unreinforced, vertical encased, reinforced with horizontal strips and combined vertical-horizontal reinforced granular piles. The loading was applied either over the entire cylindrical tank area or only over the area of granular piles. The effects of various parameters such as reinforcement, encasement stiffness, shear strength of clay, length and diameter of granular piles have been studied. Experimental results in the form of vertical load intensitysettlement relationship have been compared with that obtained from PLAXIS 3D. The results of laboratory model tests indicated significant influence of reinforcement on the ultimate load intensity of granular piles and ultimate bearing capacity of treated ground. Lateral bulging in reinforced granular piles has also been controlled by incorporating geosynthetic materials.
\end{abstract}

Keywords Ground improvement · Stone columns · Geogrid · Geotextile · FEM

Murtaza Hasan

murtazadce@gmail.com

N. K. Samadhiya

nksamfce@iitr.ac.in

1 Department of Civil Engineering, Indian Institute of Technology Roorkee, Roorkee 247667, India

\section{Introduction}

Numerous ground improvement techniques have been developed throughout the course of human history for structural construction on unsuitable sites having very poor geotechnical properties. The structures are subjected to excessive settlement, leading to stability issues, due to very low strength and high compressibility of soft clay. Granular piles (also known as stone columns) are constructed in soft clays by partial replacement of unsuitable native soil with dense and highly permeable granular material to improve the bearing capacity, to reduce settlements and to increase the rate of consolidation [1-3]. Under compressive load, granular piles fail in bulging, sliding and general shear [4-7]. The load carrying capacity of the granular piles depends on lateral resistance offered by surrounding soil. In very soft clays where granular piles do not achieve significant load capacity due to poor lateral confinement, geosynthetic encased granular piles are used to increase stiffness and reduce bulging by mobilisation of hoop stress in reinforced material [8-10]. In the past, laboratory model tests have been conducted on geotextile as well as geogrid vertical encased end bearing granular piles [10-16]. The reinforcement in the form of horizontal strips, placed at regular spacing in granular piles enhance the load carrying capacity and control bulging by mobilising frictional resistance between strips and stone aggregates [17-20]. Numerical studies have also performed by various researchers on geosynthetic encased granular piles [9, 12, 21-23]. Many authors [24-27] performed field scale load tests on vertical encased granular piles; however no literature is available on in situ tests carried out on granular piles reinforced with horizontal strips. Shivashankar et al. [28] investigated granular piles reinforced with vertical nails and found higher load carrying capacity and lesser 
bulging as compared to ordinary granular piles. Kumar et al. [29] studied combined effect of vacuum consolidation and geosynthetic encased granular piles and observed that both stiffness and load carrying capacity of the piles increase significantly after the application of vacuum.

Very limited experimental work is reported on granular piles not resting on firm stratum but have their tips embedded in clayey soil layer. No literature is available on combined effect of vertical-horizontal reinforced granular piles. In the present study, a series of laboratory model tests were performed in a circular unit cell tank on very soft clay reinforced with floating as well as end bearing granular piles. The tests were conducted on unreinforced, vertical encased, with horizontal strips and combined verticalhorizontal reinforced floating granular piles. The parameters included in this study are reinforcement, shear strength of clay, encasement stiffness, length and diameter of granular piles. Numerical analysis was also performed by using finite element software, PLAXIS 3D.

\section{Experimental Programme}

Details of experimental programme are given in Table 1. The laboratory model tests were carried out on single granular piles having 75 and $90 \mathrm{~mm}$ diameter. The granular piles were formed in soft clay bed in a cylindrical tank of $200 \mathrm{~mm}$ diameter with height ranging from 525 to
$630 \mathrm{~mm}$. The length of granular piles was kept as $5 d(375$ and $450 \mathrm{~mm}$ ) in case of floating piles to $7 d(525$ and $630 \mathrm{~mm}$ ) for end bearing piles, where $d$ is the diameter of the pile. The depth of the test tank below 75 and $90 \mathrm{~mm}$ diameter floating granular pile was kept as 150 and $180 \mathrm{~mm}$ respectively. Unit cell concept was simulated around each granular pile by assuming piles in a triangular pattern. Ghazavi and Afshar [10] performed laboratory tests on geosynthetic encased stone columns and concluded that ultimate capacity of stone columns increases with increase in the depth of encasement. Almeida et al. [24] installed vertical reinforced granular piles of $80 \mathrm{~cm}$ in diameter, $11 \mathrm{~m}$ in length in the field. Granular piles were encased by seamless woven geotextile throughout the length of pile. In field studies, various authors $[25,26]$ also provided vertical geotextile reinforcement for whole length of granular piles. Therefore in the present experimental work, full encasement for vertical, horizontal and combined reinforced granular piles was adopted. Geotextile and geogrid were used for vertical encasement and horizontal strips respectively. The schematic diagram is presented in Fig. 1. Circular strips of geogrid, having diameter $10 \mathrm{~mm}$ less than the granular piles, were used over the entire length of granular piles. These strips were placed at three different centre to centre spacing $(S)$ of 25,50 and $70 \mathrm{~mm}$. First geogrid strip in each case was placed $25 \mathrm{~mm}$ below the loading plate. Tests were conducted with two different area replacement ratios, $A_{r}$ (ratio of the area of the granular

Table 1 Details of experimental programme

\begin{tabular}{|c|c|c|c|c|c|c|}
\hline Test description & $\begin{array}{l}\text { Pile } \\
\text { diameter } \\
(\mathrm{mm})\end{array}$ & $\begin{array}{l}\text { Reinforcing material } \\
\text { type }\end{array}$ & $\begin{array}{l}\text { Strip } \\
\text { spacing } \\
(\mathrm{mm})\end{array}$ & $\begin{array}{l}\text { Pile } \\
\text { alone } \\
\text { loaded }\end{array}$ & $\begin{array}{l}\text { Entire } \\
\text { area } \\
\text { loaded }\end{array}$ & Tests \\
\hline Clay bed & - & - & - & $\checkmark$ & $\checkmark$ & 2 \\
\hline \multicolumn{7}{|l|}{ Unreinforced } \\
\hline \multirow[t]{2}{*}{ Floating } & 75 & - & & $\checkmark$ & $\checkmark$ & 2 \\
\hline & 90 & - & - & $\checkmark$ & - & 1 \\
\hline End bearing & 75 & - & - & $\checkmark$ & $\checkmark$ & 2 \\
\hline \multicolumn{7}{|l|}{ Vertical encased } \\
\hline \multirow[t]{2}{*}{ Floating } & 75 & Geotextile & - & $\checkmark$ & $\checkmark$ & 2 \\
\hline & 90 & Geotextile & & $\checkmark$ & - & 1 \\
\hline End bearing & 75 & Geotextile & - & $\boldsymbol{v}$ & $\checkmark$ & 2 \\
\hline \multirow{3}{*}{$\begin{array}{l}\text { Floating granular piles with } \\
\text { horizontal strips }\end{array}$} & 75 & Geogrid & 25 & $\checkmark$ & - & 1 \\
\hline & & & 50 & $\checkmark$ & - & 1 \\
\hline & & & 70 & $\boldsymbol{v}$ & - & 1 \\
\hline \multirow{3}{*}{$\begin{array}{l}\text { Vertical and horizontal reinforced } \\
\text { floating granular piles }\end{array}$} & 75 & Geogrid and geotextile & 25 & $\boldsymbol{v}$ & $\checkmark$ & 2 \\
\hline & & & 50 & $\checkmark$ & $\checkmark$ & 2 \\
\hline & & & 70 & $\boldsymbol{v}$ & $\checkmark$ & 2 \\
\hline Total tests & & & & & & 21 \\
\hline
\end{tabular}


Fig. 1 Schematic view of granular pile with different mode of reinforcement: a geotextile as vertical encasement; b geogrid as horizontal strips; c combined reinforcement

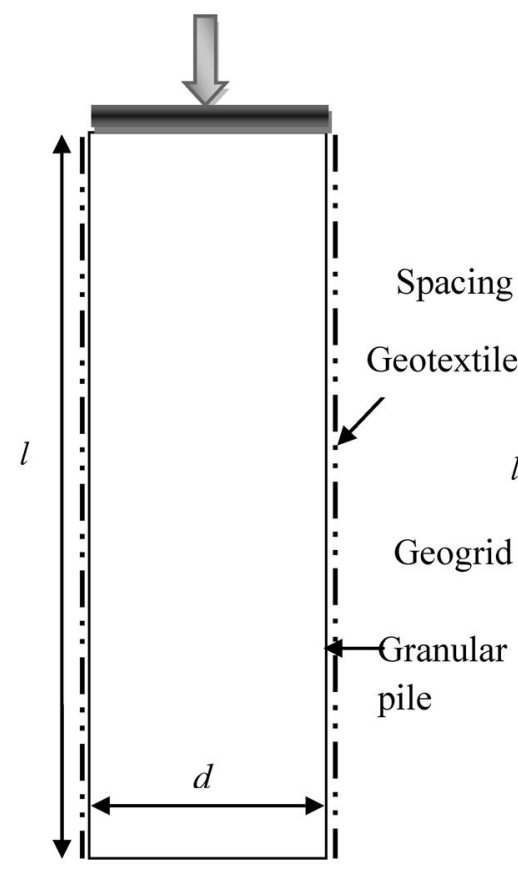

(a)

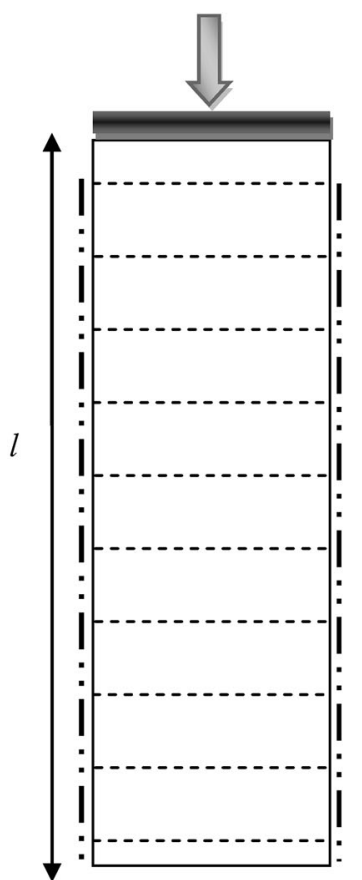

(c) pile to the total area within the unit cell), of 14 and $20 \%$. The corresponding centre to centre spacing of granular piles was kept as $2.5 \mathrm{~d}$ for $\left(A_{r}\right)=14 \%$ and $2 d$ for $\left(A_{r}\right)=20 \%$. Undrained shear strength $\left(c_{u}\right)$ of the soft clay was kept close to $5 \mathrm{kPa}$ throughout the experimental work. Tests with only granular piles loaded, were used to find the ultimate load intensity of granular pile while tests with entire area loaded, were used to obtain the ultimate bearing capacity of improved ground.

\section{Modelling Considerations}

In the present study, unit cell idealisation has been adopted to simplify the design of the apparatus needed to assess the behaviour of an interior granular pile in a large group of piles. This concept was described in detail by Barksdale and Bachus [30]. Many researchers [11, 12, 31-34] have used unit cell concept for experimental investigations on granular piles.

In practice, granular piles are constructed in typical diameters $(d)$ varying between $0.6 \mathrm{~m}$ in case of stiff clays to $1.1 \mathrm{~m}$ in very soft clays and lengths ranging from 5 to $20 \mathrm{~m}$ [35]. Well graded stones aggregates of size (k) 2-75 $\mathrm{mm}$ are used, so that the ratio $d / k$ lies typically in the range of 8 and 550 [36]. In the present study, the dimensions are reduced by an appropriate scale factor to simulate the behaviour of granular piles installed in the field. Following parameters were considered to be scaled down: (i) ratio of granular pile diameter to unit cell diameter, (ii) ratio of length to diameter of granular pile and (iii) ratio of pile diameter to aggregate size. The pile diameters used in the model tests were 75 and $90 \mathrm{~mm}$. The particle size of crushed stones was kept between 2 and $6.3 \mathrm{~mm}$, so that the ratio of $d / \mathrm{k}$ in model test lies between 8 and 45 . In the field, the ratio $l / d$ is varied from 4.5 to 20 whereas in the present study the ratio $l / d$ is kept from 5 to 7 , where $l$ is length of pile. Reinforced granular piles are commonly used in soft clayey soils (undrained shear strength less than $7 \mathrm{kPa}$ ) to control lateral confinement $[11,12,20]$. Undrained shear strength of clay in the present study has been kept close to $5 \mathrm{kPa}$. Tensile strength of geosynthetic materials were also reduced as per scaling laws proposed by Iai [37], the relationship between prototype-scale reinforcement stiffness $\left(J_{P}\right)$ and model-scale stiffness $\left(J_{m}\right)$ can be calculated as $J_{P}=J_{m} \lambda^{2}$, where $1 / \lambda$ is the model scale. Various researchers [9-12] used tensile strength of geosynthetic material in the range of 1.5-20 $\mathrm{kN} / \mathrm{m}$. Geotextile and geogrid having tensile strength of 4.4 and $8.96 \mathrm{kN} / \mathrm{m}$ respectively were used in this laboratory investigation. Granular pile spacing broadly varies in the range of 2 to 3 times the diameter of the pile. Since the equilateral triangular pattern gives the densest packing, hence the granular piles have been assumed to be installed in the same pattern as well as the in same spacing $[30,36]$.

\section{Test Set Up}

A schematic view of test setup for granular pile laboratory model tests is shown in Fig. 2. Vertical load was applied either over the entire cross sectional area of the cylindrical 


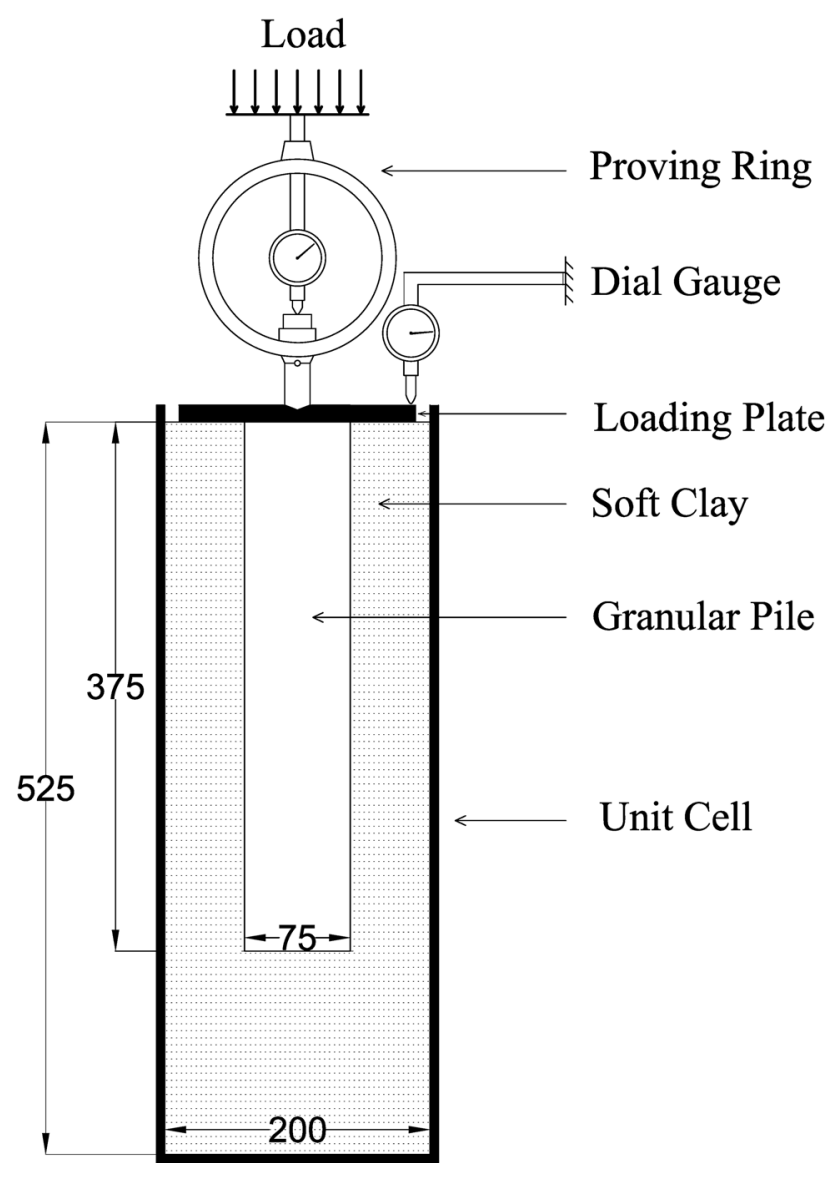

Fig. 2 Schematic view of test setup (75 $\mathrm{mm}$ diameter floating granular pile)

tank area or only over the area of granular pile. In case when only granular pile was loaded, the load was applied through a $15 \mathrm{~mm}$ thick loading plate having diameter equal to granular pile. However in case when the entire area was loaded, the load was applied through a steel plate of diameter $10 \mathrm{~mm}$ less than the inside diameter of the test tank. A proving ring was used to measure the applied load. The load was applied at a constant displacement rate of $1.2 \mathrm{~mm} / \mathrm{min}$. Dial gauge was used to measure the settlement of plate. Loading period is kept short to ensure undrained loading condition which simulates loading during construction.

\section{Properties of Materials Used}

Clay, crushed stone aggregates and geosynthetic were used in the present study. The clay from Moradabad, India was collected and transported to Geotechnical Engineering Laboratory of the authors' host institute. It has been classified as CI as per IS: 1498:2000 [38]. The dried clay was converted into fine powder by grinding and stored in air dried room. Physical properties of clay are listed in
Table 2. The particle size distribution curves for both clay and crushed stones were obtained by mechanical sieve analysis. Hydrometer analysis was also performed for clay. Particle size distribution curves are shown in Fig. 3. Crushed stones aggregates in size range $2-6.3 \mathrm{~mm}$ have been used to form granular piles. The maximum and minimum dry unit weights of the aggregate are 15.04 and $13.41 \mathrm{kN} /$ $\mathrm{m}^{3}$ respectively. Other properties of the aggregate are given in Table 3. The relative density of the granular pile material was considered $70 \%$ (corresponding to $14.51 \mathrm{kN} / \mathrm{m}^{3}$ dry unit weight) to ensure negligible bulging during installation of pile.

Two different geosynthetic materials, nonwoven geotextile and biaxial geogrid were used as vertical encasement and horizontal strips respectively. The properties of geosynthetic materials used are listed in Table 4. The ultimate tensile strength of geosynthetic was determined from standard wide-width tension tests (ASTM D4595) [39]. The tensile stress v/s strain plots are shown in Fig. 4. Geotextile was patched by special glue to form a hollow tube with an overlapping width of $20 \mathrm{~mm}$ for the encasement of the granular pile. Ultimate seam strength of glued geotextile was also determined with specimen having a horizontal seam at mid length. The ultimate strength observed from tensile tests on glued geotextile was comparable to that of unpatched geotextile.

\section{Preparation of Clay Bed}

Clay bed having undrained shear strength, $5 \mathrm{kPa}$ (corresponding to $34 \%$ water content) was prepared for all experiments in the present study. Height of clay bed was kept 525 and $630 \mathrm{~mm}$ corresponding to 75 and $90 \mathrm{~mm}$ diameter of granular piles respectively. The undrained shear strength for varying moisture content was determined by laboratory unconfined compression tests on a cylindrical specimen of $38 \mathrm{~mm}$ diameter and $76 \mathrm{~mm}$ height. Hit and trial method was used to find water content corresponding to undrained shear strength of $5 \mathrm{kPa}$. Based on the results,

Table 2 Physical properties of clay

\begin{tabular}{ll}
\hline Properties & Value \\
\hline Specific gravity & 2.73 \\
Optimum moisture content $(\%)$ & 17.56 \\
Maximum dry unit weight $\left(\mathrm{kN} / \mathrm{m}^{3}\right)$ & 17.22 \\
Liquid limit, $w_{l}(\%)$ & 48 \\
Plastic limit, $w_{P}(\%)$ & 18 \\
Plasticity index $(\%)$ & 30 \\
Dry unit weight at $34 \%$ water content $\left(\mathrm{kN} / \mathrm{m}^{3}\right)$ & 13.85 \\
Undrained shear strength at $34 \%$ water content $(\mathrm{kPa})$ & $\approx 5$ \\
Classification & $\mathrm{CI}$ \\
\hline
\end{tabular}




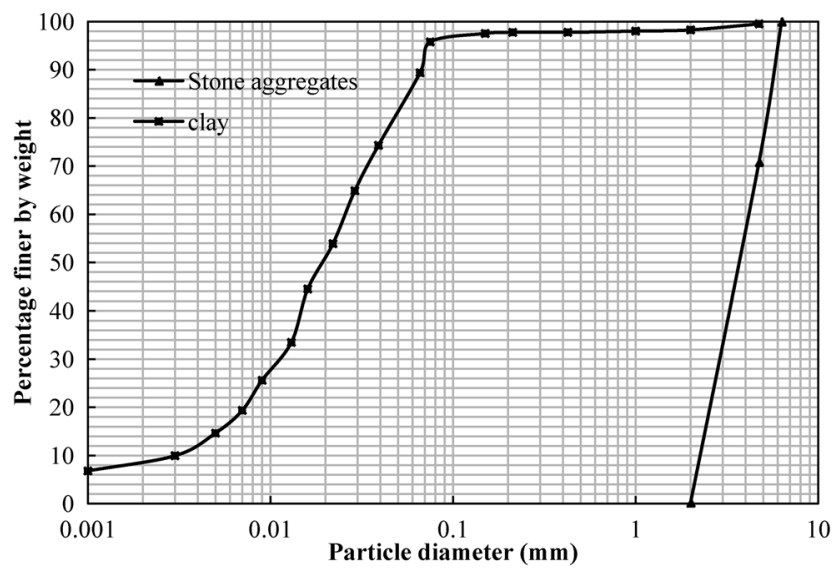

Fig. 3 Particle size distribution curves for clay and stone aggregates

Table 3 Physical properties of crushed stone aggregates

\begin{tabular}{ll}
\hline Properties & Value \\
\hline Specific gravity & 2.68 \\
Maximum dry unit weight $\left(\mathrm{kN} / \mathrm{m}^{3}\right)$ & 15.04 \\
Minimum dry unit weight $\left(\mathrm{kN} / \mathrm{m}^{3}\right)$ & 13.41 \\
Dry unit weight at $70 \%$ relative density $\left(\mathrm{kN} / \mathrm{m}^{3}\right)$ & 14.51 \\
Angle of internal friction $(\phi)$ at $70 \%$ relative density $\left({ }^{\circ}\right)$ & 43 \\
\hline
\end{tabular}

Table 4 Properties of geosynthetic materials

\begin{tabular}{lll}
\hline $\begin{array}{l}\text { Properties } \\
\text { Type }\end{array}$ & $\begin{array}{l}\text { Geotextile } \\
\text { Nonwoven }\end{array}$ & $\begin{array}{l}\text { Geogrid } \\
\text { Biaxial }\end{array}$ \\
\hline Ultimate tensile strength $(\mathrm{kN} / \mathrm{m})$ & 4.41 & 7.96 \\
Strain at peak load $(\%)$ & 54.62 & 20.21 \\
Axial stiffness $(\mathrm{kN} / \mathrm{m})$ & 8.07 & 38.01 \\
Ultimate seam strength $(\mathrm{kN} / \mathrm{m})$ & 3.94 & - \\
Thickness $(\mathrm{mm})$ & 2 & 1.5 \\
\hline
\end{tabular}

as shown in Fig. 5, water content for the required undrained shear strength of $5 \mathrm{kPa}$ was found to be $34 \%$ and corresponding dry unit weight was $13.85 \mathrm{kN} / \mathrm{m}^{3}$. The required quantity of water (34\%) was mixed thoroughly with clay in a large steel container to ensure uniform water content throughout clay. A thin coat of grease was applied on the inner surface of cylindrical tank to create frictionless boundary between clay and inner wall. Tank was filled in layers, each of $30 \mathrm{~mm}$ height and then compacted properly. After completing clay bed, top surface of tank was covered and left for 2 days to gain uniformity. Vane shear tests were conducted at the centre of clay bed to verify the undrained shear strength before installation of granular piles. All vane shear tests gave reasonable results, close to $5 \mathrm{kPa}$. Enough quantity of clay was stored to maintain

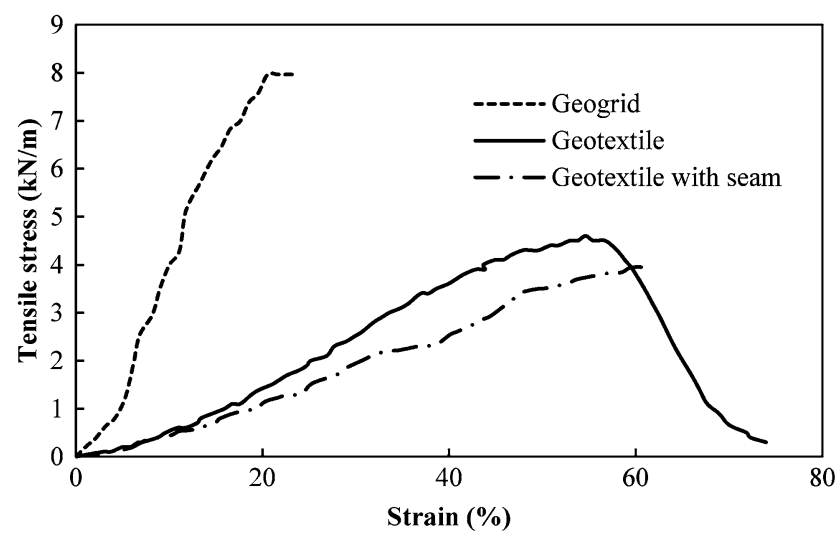

Fig. 4 Tensile stress strain behaviour of geosynthetic materials

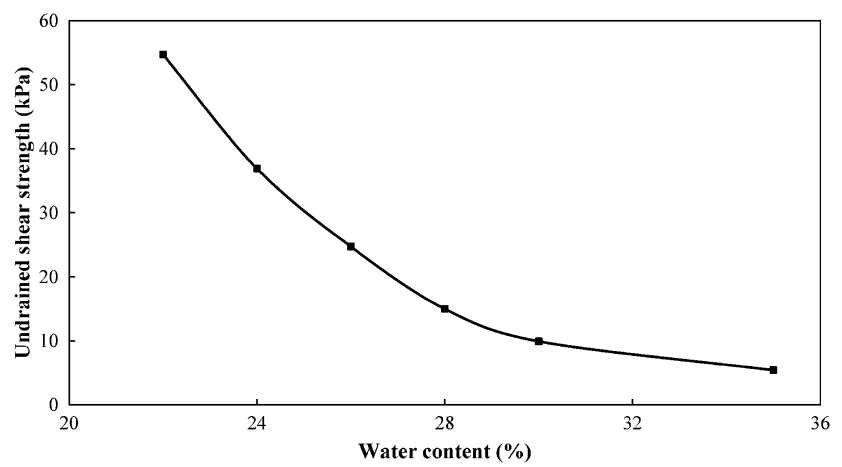

Fig. 5 Variation of undrained shear strength with water content

uniformity in the tests and virgin clay was used in each model test for better control on moisture content.

\section{Construction of Granular Pile}

Granular piles of diameter 75 and $90 \mathrm{~mm}$ were constructed by using replacement method in all model tests. It is worth mentioning here that generally displacement granular piles are popular in soft clays as the installation is economical and faster. However, the displacement technique is difficult to implement in a small scale laboratory model tests. Black et al. [40] conducted trial tests and concluded generation of suction during removal of the poker which caused collapse of the cavity whereas the replacement technique is known to produce the granular piles of excellent consistency. With the help of auger guide, a thin seamless steel pipe, of outer diameter equivalent to granular pile diameter, was inserted smoothly in the centre of clay bed up to the desired height of granular pile (Fig. 6a). Oil was applied on both outer and inner surfaces of steel pipe to avoid the disturbance in surrounding clay, to allow easy insertion and withdrawal and to avoid sticking of clay to pipe. Two different helical steel augers of diameter, $2 \mathrm{~mm}$ less than that of steel pipe, were fabricated to scoop out clay within the steel pipe. 
Fig. 6 Construction and loading of granular pile (a) insertion of steel pipe, (b) pile and clay bed, $(c)$ loading arrangement

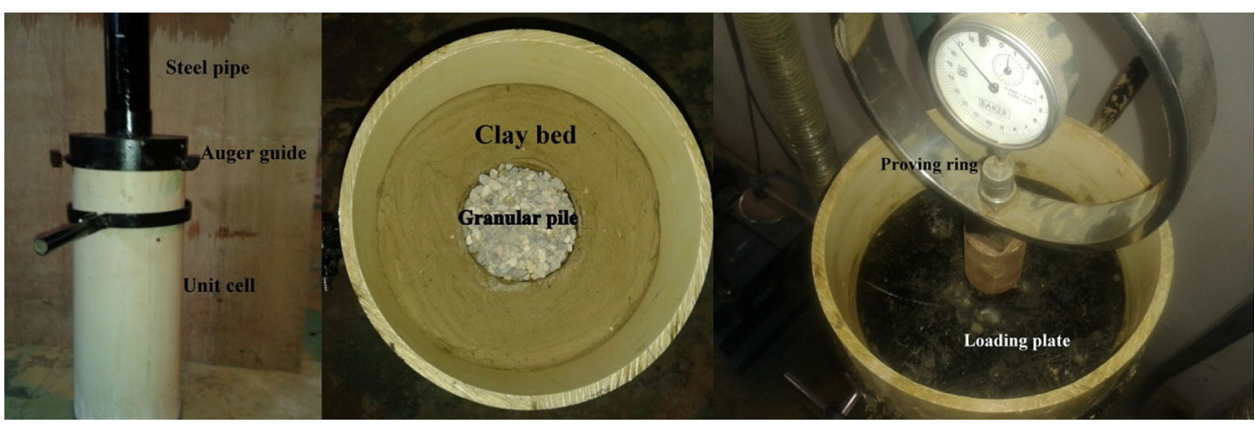

(a) (c)
Approximately, $30 \mathrm{~mm}$ height of clay was removed in a single stroke to avoid suction between pipe and auger. Process was repeated until desired height of granular pile was reached. For vertical encased granular pile, circular wooden rod of diameter $3 \mathrm{~mm}$ less than pile diameter was used for vertical placing of geotextile in excavated hole. Then crushed stone aggregates in predetermined quantity were charged into hole in 10 layers to maintain dry unit weight $\left(14.51 \mathrm{kN} / \mathrm{m}^{3}\right)$. Each layer was light compacted so as to ensure that no lateral bulging occurs during the construction of granular pile. A $2.5 \mathrm{~kg}$ circular steel tamper (5 blows, $150 \mathrm{~mm}$ drop) was used to achieve a uniform dry unit weight. In case of reinforced granular pile with horizontal strips, the aggregates in quantity required between two geogrid layers, was poured and then compacted within hole before placing next circular geogrid strip. Figure 6b shows formation of the granular pile. Stone aggregates used were of strong quality (granite) to avoid crushing while loading in test. Fresh aggregates were used for each test for better results.

\section{Test Procedure}

Vertical load intensity settlement behaviour of untreated clay bed and granular pile treated clay were obtained by applying vertical load through rigid loading frame. The load was applied either over the entire cross sectional area of cylindrical tank or only over the granular pile. Short term loading and displacement controlled tests with displacement rate of $1.2 \mathrm{~mm} / \mathrm{min}$ were conducted. Load was measured by proving ring as shown in Fig. 6c. In case of granular pile being loaded alone, loading was applied till failure or up to displacement of $35 \mathrm{~mm}$. In case when entire area is loaded, the load was applied in a similar manner until the settlement exceeded $25 \mathrm{~mm}$. After completion of each model test, aggregates were removed; slurry of plaster of Paris was poured into the hole created and allowed to set for $24 \mathrm{~h}$ to take up the shape of the deformed granular pile. Surrounding clay was removed carefully in order to obtain the deformed shape of granular pile and then painted in white colour for better visibility of bulging.

\section{Finite Element Analysis}

FEM study was carried out by finite element software, PLAXIS 3D. The vertical load intensity settlement behaviour was compared with that obtained by laboratory investigations. PLAXIS 3D model was validated by simulating load settlement behaviour of single sand-fibre mixed granular pile based on short term model test in the laboratory carried out by Basu [41]. Basu [41] conducted test on rectangular tank of size $0.2625 \mathrm{~m} \times 0.2625 \mathrm{~m} \times 0.6 \mathrm{~m}$. A granular pile of $75 \mathrm{~mm}$ diameter and $600 \mathrm{~mm}$ length was formed in the centre of tank and loaded with $75 \mathrm{~mm}$ diameter circular plate. A model was generated in PLAXIS 3D and analysed using Mohr-Coulomb failure criterion. The material properties used in the modelling are given in Table 5 . Generated mesh with medium element distribution and total displacements after failure in model are shown in Fig. 7. The comparison of experimental and PLAXIS 3D results is presented in Fig. 8. The results are in reasonably good agreement.

In the present study, short term loading tests were performed on granular piles. Consolidation effect of clay was not taken into account. The linear elastic perfectly plastic Mohr-Coulomb model, which has also been adopted by various authors [10, 21, 23, 31, 34] for similar study, has been used for clay and stone aggregates. This model is mostly used to compute realistic bearing capacity and collapse loads of footing as well as other application in which the failure behaviour of soil plays dominant role. $\mathrm{Ng}$ and Tan [42] stated that stone column in the unit cell shared about 4-5 times more loads than the surrounding soils throughout the column depth. They concluded that PLAXIS 2D and 3D models give results that are similar to each other especially on the settlement performance and the failure mechanism. Therefore shape of unit cell does not affect the vertical load intensity-settlement 
Table 5 Material properties for PLAXIS 3D

\begin{tabular}{llllll}
\hline Parameters & \multicolumn{2}{l}{ Basu [41] } & & Present study & \\
\cline { 2 - 3 } & Clay & Sand-fibre mix & & Clay & Stone aggregates \\
\hline Young's modulus, $E(\mathrm{kPa})$ & 250 & 6700 & & 420 & 42,500 \\
Cohesion $(\mathrm{kPa})$ & 16.0 & 15.55 & & As per Table 6 & 0 \\
Angle of internal friction, $\phi\left(^{\circ}\right)$ & 0 & 34.47 & & 0 & 43 \\
Poisson's ratio, $\mu$ & 0.3 & 0.3 & & 0.48 & 0.3 \\
Dry unit weight $\left(\mathrm{kN} / \mathrm{m}^{3}\right)$ & 14.90 & 18.0 & & 13.85 & 14.51 \\
Bulk unit weight $\left(\mathrm{kN} / \mathrm{m}^{3}\right)$ & 19.37 & 18.0 & & 18.58 & 14.51 \\
\hline
\end{tabular}
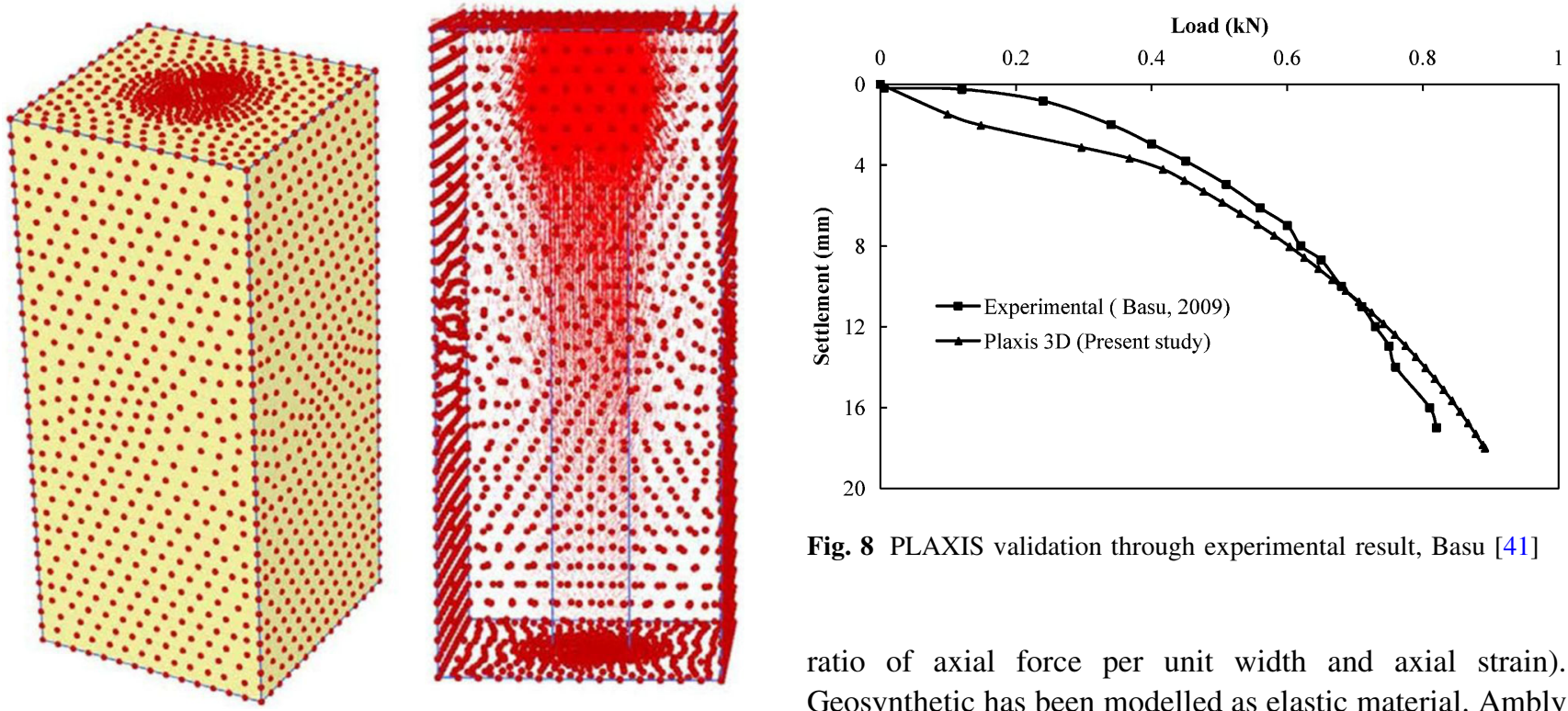

Fig. 8 PLAXIS validation through experimental result, Basu [41]

ratio of axial force per unit width and axial strain). Geosynthetic has been modelled as elastic material. Ambly and Gandhi [31] carried out analysis of stone columns without interface element and stated that the deformation of the column is mainly by radial bulging and no significant shear is possible. The interface between a stone column and clay is a mixed zone where the shear strength properties can vary, depending on the method of installation. Therefore an interface element is not used in the present study. The meshes used for the analysis of vertical and horizontal reinforced floating granular pile models $(75 \mathrm{~mm}$ diameter) are presented in Fig. 9.

\section{Results and Discussion}

\section{Comparison of Laboratory Model Tests and Fem When Granular Pile Alone is Loaded}

This analysis has been conducted to estimate the ultimate load intensity of granular pile. The results of experimental and FEM analysis in terms of vertical load intensity-settlement behaviour of clay bed, unreinforced and vertical encased floating granular pile are presented in Fig. 10a. Perusal of Fig. 10a shows that the results are in close 


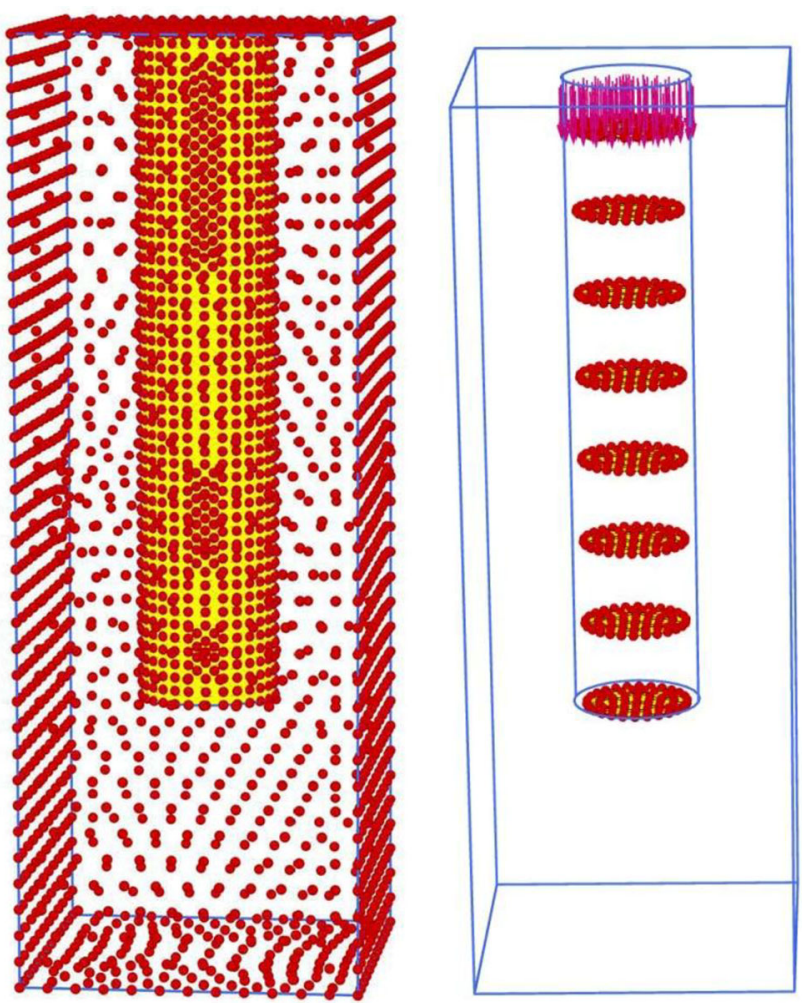

Fig. 9 Vertical and horizontal reinforced floating granular piles models

agreement. The results have also been summarised in Table 6. The ultimate load intensity for unreinforced and vertical encased granular pile from laboratory investigation was found to increase by 195 and $440 \%$ respectively as compared to clay bed. However the increase in ultimate load intensity for encased granular pile is $83 \%$ as that of unreinforced granular pile. Figure $10 \mathrm{~b}$ shows vertical load intensity settlement plots for both experimental and FEM analysis in case of end bearing granular pile. It was found that ultimate load intensity for unreinforced and encased granular pile increased by 238 and $550 \%$ respectively as compared to clay bed. The increment in ultimate load intensity of unreinforced end bearing pile was found to be $15 \%$ as compared to unreinforced floating granular pile, whereas it increased by $21 \%$ for reinforced end bearing pile with respect to reinforced floating granular pile. The encased granular pile offers higher resistant to surrounding clay by mobilising hoop stress in geotextile and thereby improving the lateral confinement.

Laboratory model tests were also conducted to investigate the effect of diameter of floating granular piles. Figure 11 shows the comparison of results of experimental and FEM analysis in terms of vertical load intensity settlement relationship for 75 and $90 \mathrm{~mm}$ diameter of floating granular pile. The ultimate load intensity was found almost

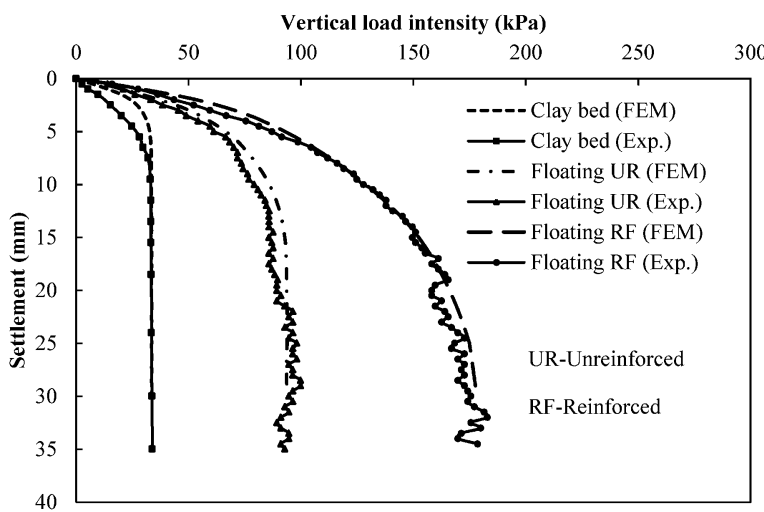

(a)

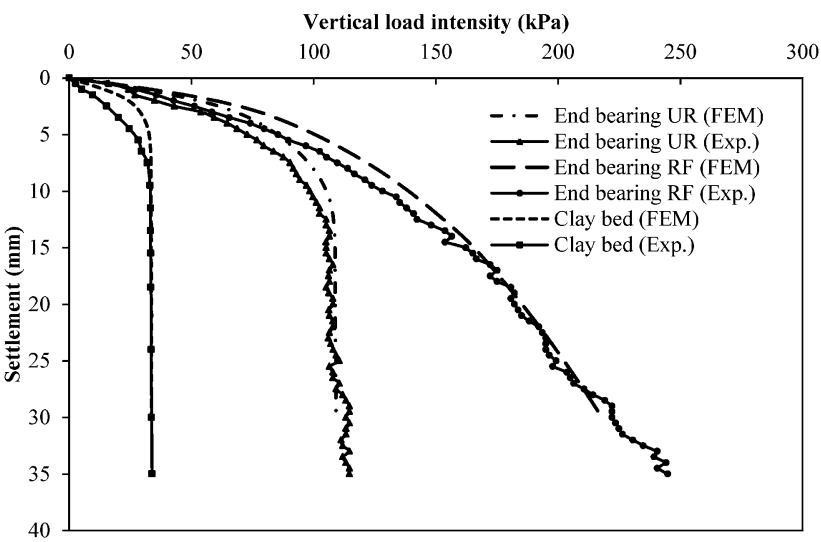

(b)

Fig. 10 Vertical load intensity settlement behaviour of granular piles; a floating, $\mathbf{b}$ end bearing

same for unreinforced granular piles, whereas the ultimate load intensity of vertical encased granular piles is found to decrease with increase in the diameter of granular piles. Same pattern was observed by various researchers $[9,11,20]$. The ultimate load intensity of $90 \mathrm{~mm}$ diameter reinforced granular pile decreased by $16 \%$ over the $75 \mathrm{~mm}$ diameter reinforced granular piles.

Numerical analysis has also been extended to study the influence of undrained shear strength of the soft clay and encasement stiffness on the behaviour of floating granular piles. The undrained shear strength of clay bed was kept as 3, 6, 9 and $12 \mathrm{kPa}$. The variation of ultimate load intensity with undrained shear strength is shown in Fig. 12. The ultimate load intensity for granular piles increased with the increase in undrained shear strength of clay. It may be attributed to the higher lateral resistance provided by clay. The encasement stiffness of reinforced floating granular pile was varied in the range of $8-250 \mathrm{kN} / \mathrm{m}$. The effect of stiffness on the ultimate load intensity of floating granular pile is shown in Fig. 13. The ultimate load intensity has been found to increase up to $50 \mathrm{kN} / \mathrm{m}$ stiffness and then is improved marginally for higher stiffness. It may be noted 
Table 6 Results of laboratory model tests and FEM analysis

\begin{tabular}{|c|c|c|c|c|c|c|c|c|c|}
\hline \multirow[t]{3}{*}{ Test description } & \multirow{3}{*}{$\begin{array}{l}\text { Pile } \\
\text { diameter } \\
(\mathrm{mm})\end{array}$} & \multirow{3}{*}{$\begin{array}{l}\text { Reinforcing } \\
\text { material type }\end{array}$} & \multirow{3}{*}{$\begin{array}{l}\text { Strip } \\
\text { spacing } \\
(\mathrm{mm})\end{array}$} & \multicolumn{3}{|c|}{ Pile alone loaded } & \multicolumn{3}{|c|}{ Entire area loaded } \\
\hline & & & & \multirow[t]{2}{*}{$\begin{array}{l}c_{u} \\
(\mathrm{kPa})\end{array}$} & \multicolumn{2}{|c|}{$\begin{array}{l}\text { Ultimate load intensity } \\
(\mathrm{kPa})\end{array}$} & \multirow[t]{2}{*}{$\begin{array}{l}c_{u} \\
(\mathrm{kPa})\end{array}$} & \multicolumn{2}{|c|}{$\begin{array}{l}\text { Ultimate bearing capacity } \\
(\mathrm{kPa})\end{array}$} \\
\hline & & & & & Exp. & FEM & & Exp. & FEM \\
\hline Clay bed & - & - & - & 5.12 & 33.85 & 33.64 & 5.18 & 46.36 & 48.18 \\
\hline \multicolumn{10}{|l|}{ Unreinforced } \\
\hline \multirow[t]{2}{*}{ Floating } & 75 & - & - & 5.01 & 99.88 & 99.82 & 5.11 & 66.42 & 69.28 \\
\hline & 90 & - & - & 5.24 & 96.65 & 94.87 & - & - & - \\
\hline End bearing & 75 & - & - & 5.09 & 114.58 & 109.08 & 5.16 & 76.68 & 77.39 \\
\hline \multicolumn{10}{|l|}{ Vertical encased } \\
\hline \multirow[t]{2}{*}{ Floating } & 75 & Geotextile & - & 5.21 & 182.87 & 178.06 & 5.34 & 81.53 & 83.84 \\
\hline & 90 & Geotextile & - & 5.18 & 153.75 & 159.27 & - & - & - \\
\hline End bearing & 75 & Geotextile & - & 5.41 & 221.97 & 217.90 & 5.29 & 113.24 & 108.86 \\
\hline \multirow{3}{*}{$\begin{array}{l}\text { Floating granular piles } \\
\text { with horizontal strips }\end{array}$} & 75 & Geogrid & 25 & 5.29 & 183.55 & 185.14 & - & - & - \\
\hline & & & 50 & 5.17 & 167.90 & 176.45 & - & - & - \\
\hline & & & 70 & 5.13 & 140.86 & 137.89 & - & - & - \\
\hline \multirow{3}{*}{$\begin{array}{l}\text { Vertical and horizontal } \\
\text { reinforced floating } \\
\text { granular piles }\end{array}$} & 75 & Geogrid and geotextile & 25 & 5.32 & 198.27 & 190.25 & 5.28 & 79.16 & 83.33 \\
\hline & & & 50 & 5.28 & 180.25 & 189.99 & 5.16 & 76.15 & 76.92 \\
\hline & & & 70 & 5.15 & 178.76 & 188.68 & 5.19 & 68.82 & 66.54 \\
\hline
\end{tabular}

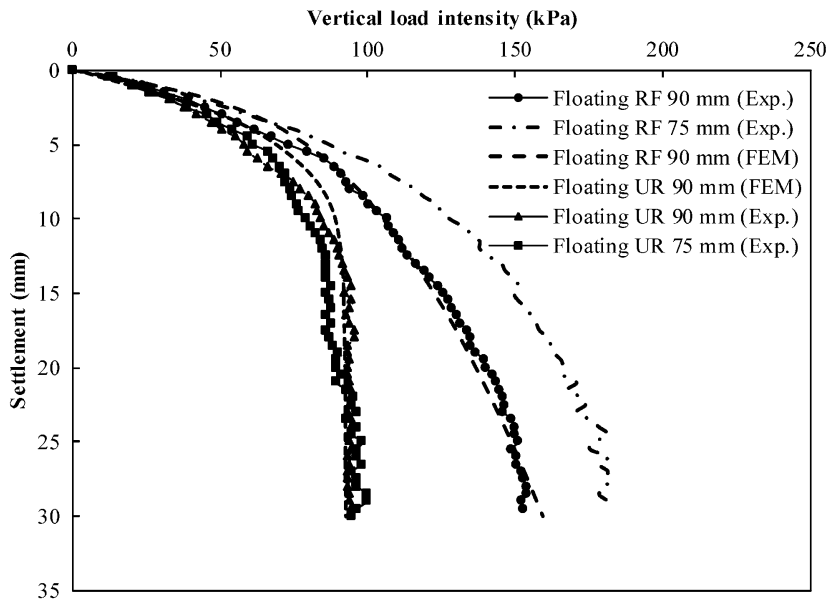

Fig. 11 Effect of diameter on vertical load intensity settlement behaviour of floating granular piles

that the floating granular piles with higher encasement stiffness start penetrating into soft clay rather than bulging.

Figure 14 presents the experimental and FEM results in terms of vertical load intensity and settlement for floating granular pile reinforced with horizontal strips with three different spacing. It was observed that ultimate load intensity of improved ground increases with reduction in vertical spacing of strips. The ultimate load intensity for 25, 50 and $70 \mathrm{~mm}$ centre to centre spaced horizontally reinforced granular pile was found to increase by 442,396 and $316 \%$ respectively as compared to clay bed and 83, 68 and $40 \%$ respectively with respect to unreinforced floating

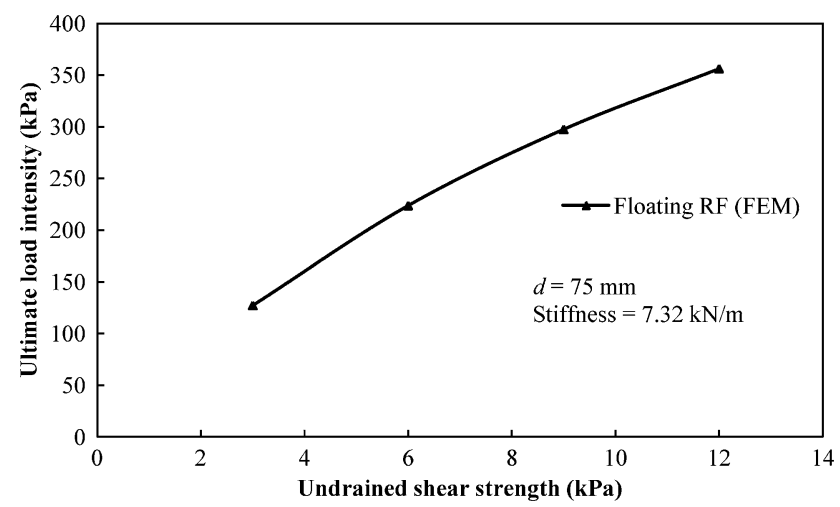

Fig. 12 Influence of undrained shear strength of clay on the ultimate load intensity

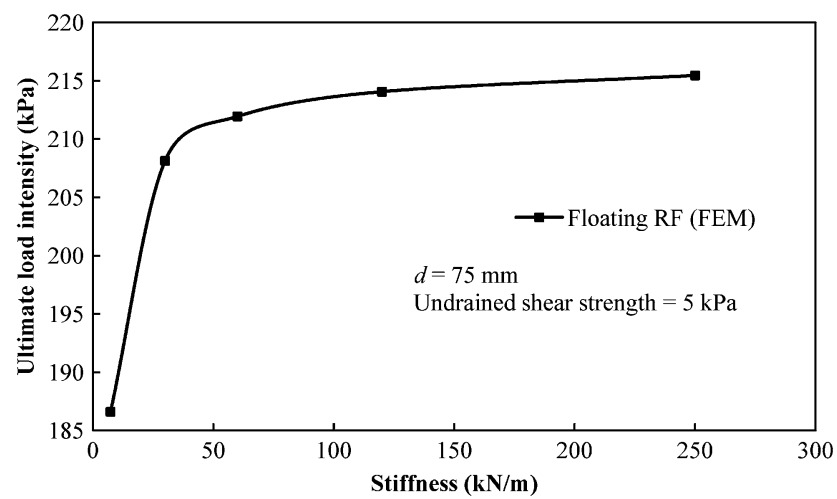

Fig. 13 Variation of the ultimate load intensity with encasement stiffness 


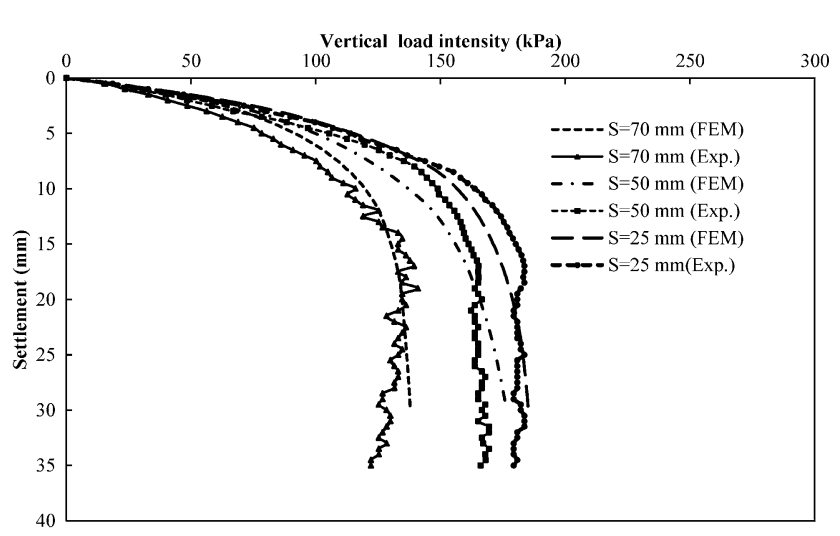

Fig. 14 Vertical load intensity settlement behaviour of horizontal reinforced floating granular piles

granular piles. It may also be noted that the increments are much higher than ultimate load intensity of the unreinforced end bearing pile. The ultimate load intensity for $25 \mathrm{~mm}$ spaced horizontal striped granular pile has been observed to be very close to that of vertical encased floating granular pile.

Laboratory model tests were also conducted to study the combined effect of vertical encased as well as horizontal strips reinforced floating granular pile. Figure 15 shows vertical load intensity settlement behaviour from experimental and FEM analysis for combined reinforced floating granular pile. The ultimate load intensity of improved ground was further found to increase with respect to that of geogrid reinforced granular pile. It was observed that the ultimate load intensity of 25,50 and $70 \mathrm{~mm}$ centre to centre spaced combined reinforced granular pile increased by 485,432 and $428 \%$ as compared to clay bed. However the horizontal spacing of geogrid strips have negligible effect in case of combined reinforced floating granular piles. The ultimate load intensity of $70 \mathrm{~mm}$ spaced horizontal striped combined granular pile was found to increase by $27 \%$ as compared to $70 \mathrm{~mm}$ spaced geogrid reinforced granular pile.

\section{Comparison of Laboratory Model Tests and Fem When Entire Area is Loaded}

Some laboratory model tests and FEM analyses have also been conducted to study the improvement in the ultimate bearing capacity of treated ground after the installation of granular pile. It represents actual field behaviour of an interior granular pile when large groups of piles are loaded simultaneously. The ultimate bearing capacities were estimated by double tangent method and have been presented in Table 6. Figures 16 and 17 present experimental and FEM results in terms of vertical load intensity settlement behaviour of clay bed, unreinforced, vertical and combined reinforced floating granular pile. The ultimate bearing

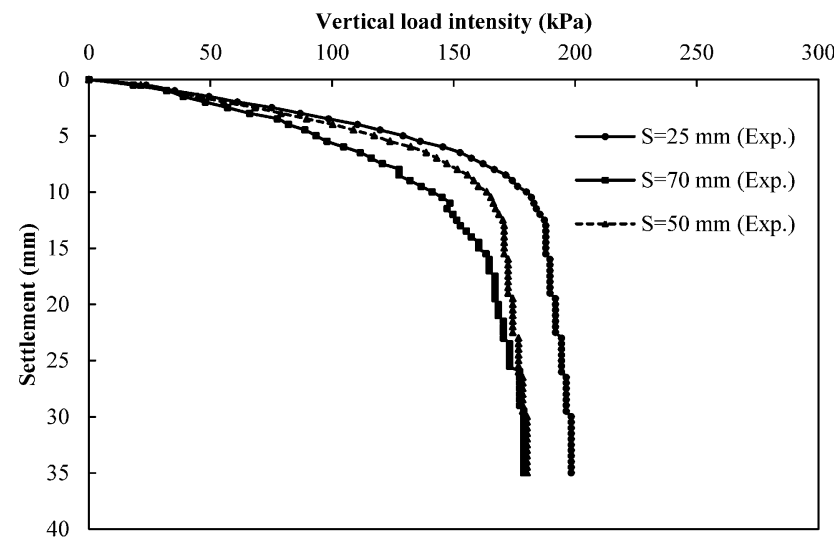

(a)

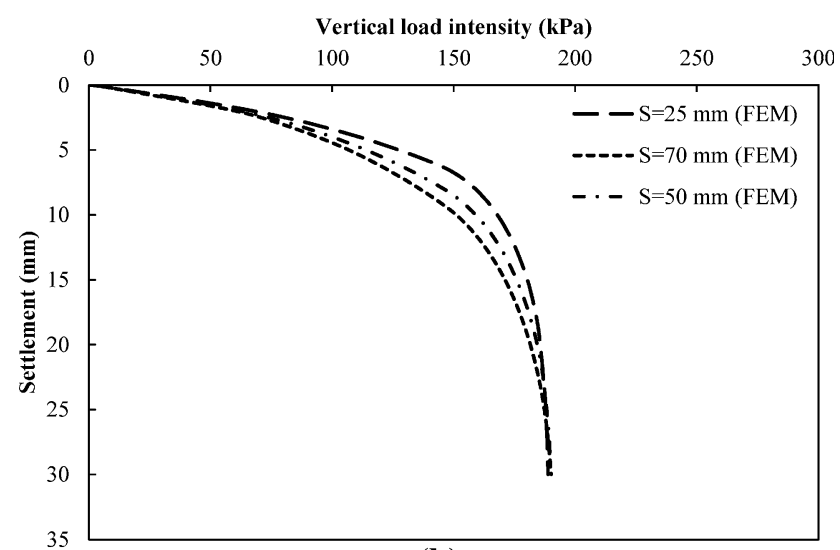

(b)

Fig. 15 Vertical load intensity settlement behaviour of combined reinforced floating granular piles; a laboratory model tests, b FEM analysis

capacity has been found to increase by 37 and $69 \%$ for unreinforced and vertical reinforced floating granular piles respectively as compared to untreated ground. The increase in ultimate bearing capacity of unreinforced and vertical reinforced end bearing pile was found to be 59 and $135 \%$ respectively over the untreated ground. It has been found that the ultimate bearing capacity of 25,50 and $70 \mathrm{~mm}$ centre to centre spaced combined reinforced floating granular pile is increased by 73,64 and $40 \%$ with respect to untreated ground.

\section{Deformation and Failure Modes}

After completion of tests, deformed shapes of granular piles were established by removing aggregates and then pouring plaster of Paris in the hole. Deformed shapes were also obtained from PLAXIS 3D studies. Figure 18a, b shows deformed shape from laboratory model and FEM analysis for $75 \mathrm{~mm}$ diameter unreinforced and vertical reinforced (floating and end bearing granular pile) when these were loaded alone. The failure is mainly attributed to 


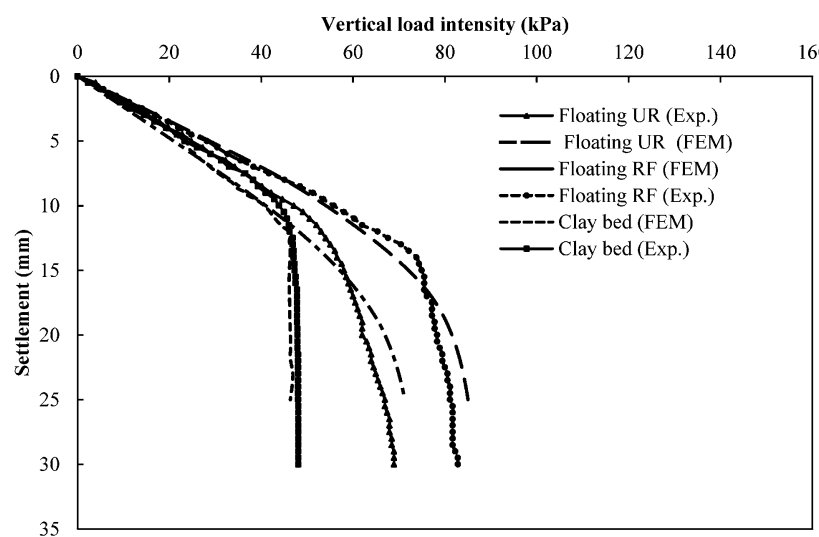

(a)

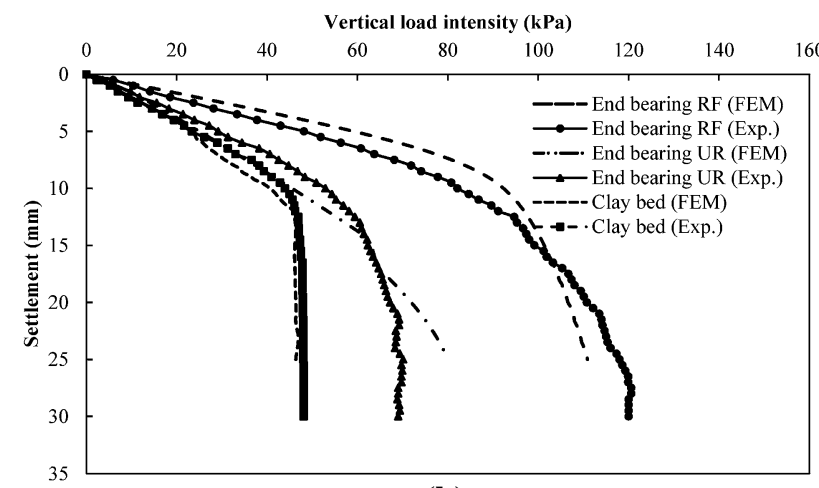

(b)

Fig. 16 Vertical load intensity settlement behaviour of granular piles (entire area loaded); a floating, $\mathbf{b}$ end bearing

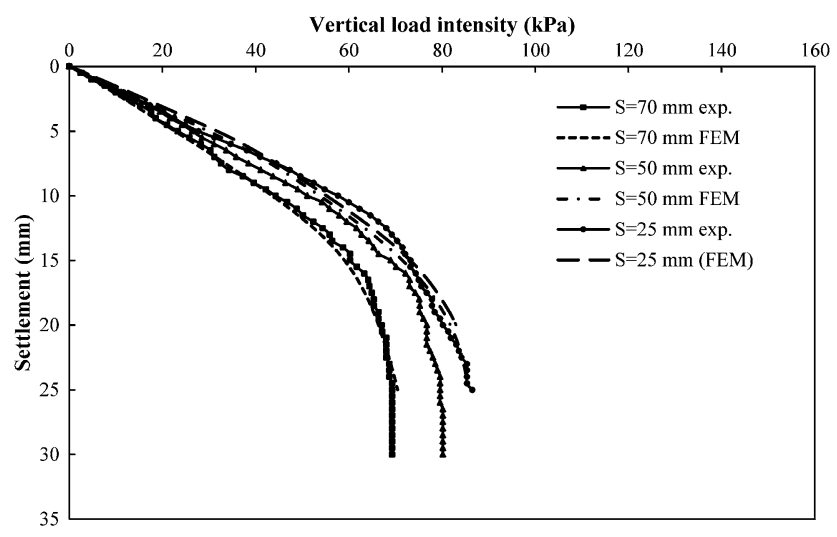

Fig. 17 Vertical load intensity settlement behaviour of combined reinforced floating granular piles (entire area loaded)

bulging due to poor lateral confinement. The reinforced floating pile also penetrated up to some depth. It may be seen that the bulging reduced in vertical reinforced granular pile due to confinement provided by geotextile. The depth of maximum bulging was observed to be in the range of 1 to 1.6 times the diameter of the pile from the top while bulging has been observed close to top of the pile in case of unreinforced granular pile. The total length of the granular

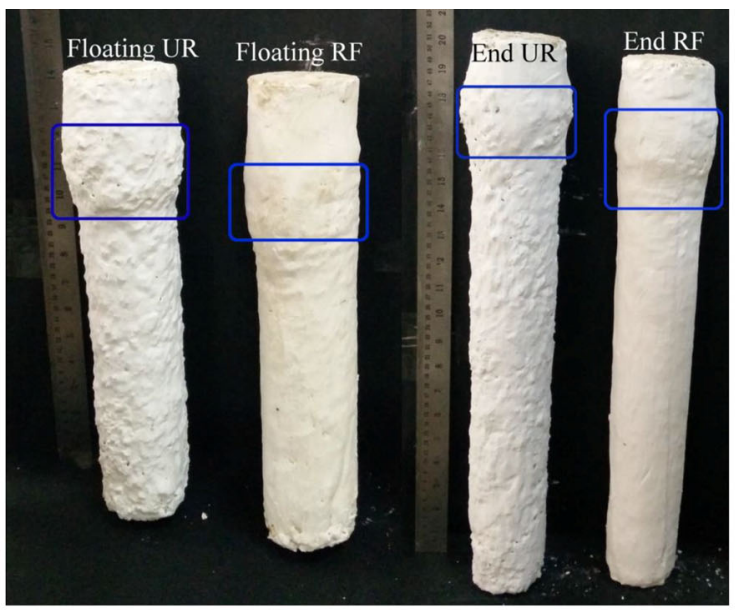

(a)
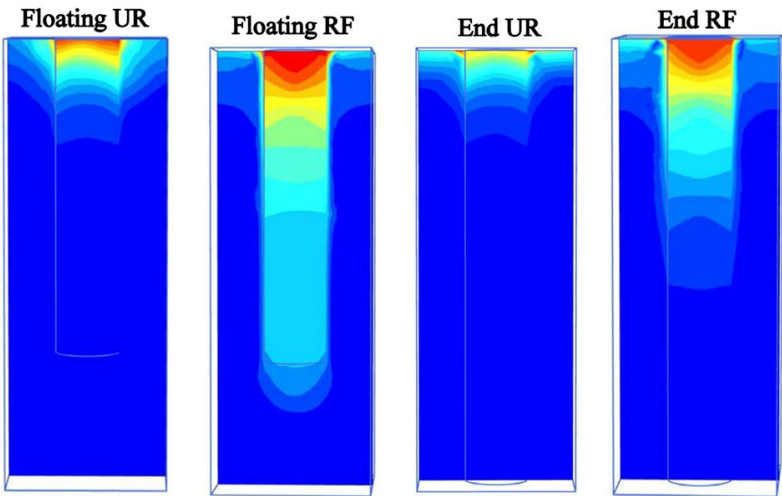

(b)

Fig. 18 Deformed shapes of $75 \mathrm{~mm}$ diameter granular piles; a laboratory model tests, b FEM

pile experiencing bulging was found to be 1.5 to 2.5 times the diameter of the pile from the top. The granular pile reinforced with $70 \mathrm{~mm}$ spaced horizontal strips (loaded alone) was observed to fail in bulging, whereas 25 and $50 \mathrm{~mm}$ spaced reinforced granular piles have been found to penetrate into clay as shown in Fig. 19a, b. The combined reinforced floating granular piles do not show bulging and penetrate into clays. Same deformation patterns were also observed in the case when entire area was loaded.

\section{Conclusions}

In the present investigation, laboratory model tests were carried out on granular piles (floating and end bearing) having diameters of 75 and $90 \mathrm{~mm}$. The effects of reinforcement, undrained shear strength of clay, encasement stiffness, diameter and length of granular piles were studied. The vertical load intensity-settlement plots from laboratory model tests were compared with that obtained from PLAXIS 3D. The following conclusions can be drawn: 


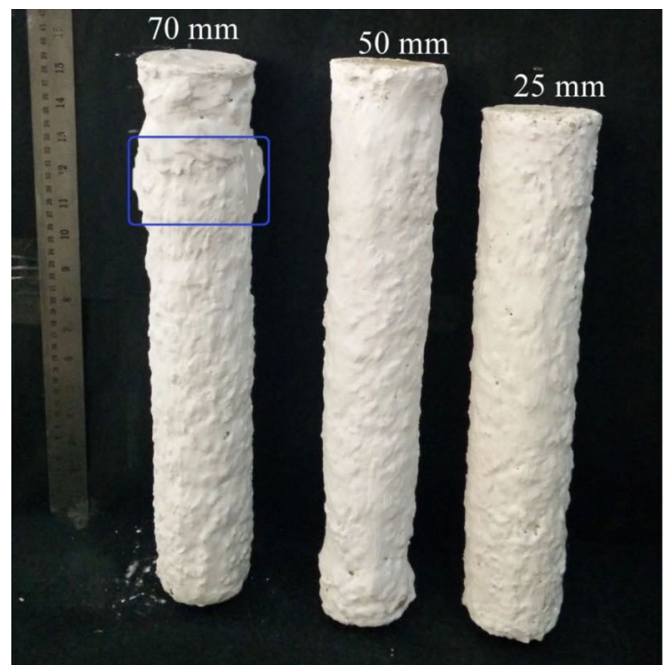

(a)
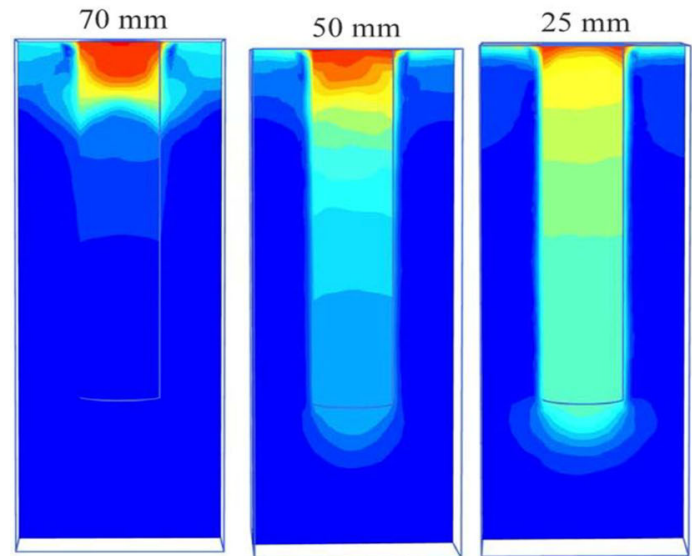

(b)

Fig. 19 Deformed shapes of horizontal striped granular piles; a laboratory model tests, b FEM

1. The ultimate load intensity of soft clay has been found to improve due to installation of granular piles. It has also further improved due to inclusion of geosynthetic in the granular piles.

2. Unreinforced end bearing granular piles can favourably be replaced by reinforced floating granular piles.

3. The ultimate load intensity of unreinforced and reinforced granular piles increases with the increase in length of the pile. It undergoes further enhancement when the undrained shear strength of clay increases.

4. For increase in the diameter of granular piles, the ultimate load intensity is almost same for unreinforced granular piles, whereas the ultimate load intensity of vertical encased granular piles decreases with the increase in diameter of granular piles.

5. Floating granular pile reinforced with horizontal strips @ $25 \mathrm{~mm} \mathrm{c} / \mathrm{c}$ spacing can be substituted for vertical encased floating granular pile. The ultimate load intensity of floating granular pile increases when the vertical spacing between geogrid strips decreases.

6. The spacing of geogrid strips has negligible effect on the ultimate load intensity of the combined reinforced floating granular piles.

7. The reinforcement provided in the granular piles controls bulging of the piles. The depth of maximum bulging in unreinforced and vertical encased granular piles lies between 1 and 1.6 times the diameters of piles. The granular piles reinforced with horizontal strips, and combined horizontal strips-vertical encasement usually does not fail in bulging but penetrate into soft clay.

8. In case when the entire area is loaded, the ultimate bearing capacity of treated ground has been found to improve by using vertical, horizontal and combined reinforced granular piles.

\section{References}

1. Greenwood DA (1970) Mechanical improvement of soils below ground surfaces. In: Proceedings, ground engineering conference, institution of civil engineers, London, pp 11-22

2. Han J, Ye SL (2001) Simplified method for consolidation rate of stone column reinforced foundation. J Geotech Geoenviron Eng ASCE 127(7):597-603

3. Castro J, Cimentada A, Costa A, Canizal J, Sagaseta C (2013) Consolidation and deformation around stone columns: comparison of theoretical and laboratory results. Comput Geotech 49:326-337

4. Hughes JMO, Withers NJ (1974) Reinforcing of soft cohesive soils with stone columns. Ground Eng 7(3):42-49

5. Hughes JMO, Withers NJ, Greenwood DA (1975) A field trial of the reinforcing effect of a stone column in soil. Geotechnique 25(1):31-44

6. Madhav MR, Vitkar PP (1978) Strip footing on weak clay stabilized with a granular trench or pile. Can Geotech J 15(4):605-609

7. Aboshi H, Ichimoto E, Harada K, Emoki M (1979) The composer-a method to improve the characteristics of soft clays by inclusion of large diameter sand columns. In: Proceedings of international conference on soil reinforcement, Paris, pp 211-216

8. Van Impe W, Silence P (1986) Improving of the bearing capacity of weak hydraulic fills by means of geotextiles. In: Proceedings of the 3rd international conference on geotextiles, Vienna, pp. 1411-1416

9. Murugesan S, Rajagopal K (2006) Geosynthetic-encased stone columns: numerical evaluation. Geotext Geomembr 24:349-358

10. Ghazavi M, Afshar JN (2013) Bearing capacity of geosynthetic encased stone columns. Geotext Geomembr 38:26-36

11. Murugesan S, Rajagopal K (2007) Model tests on geosynthtic encased stone columns. Geosynth Int J 24(6):346-354

12. Gniel J, Bouazza A (2008) Improvement of soft soils using geogrid encased granular columns. Geotext Geomembr 27(3): $167-175$

13. Wu CS, Hong YS (2009) Laboratory tests on geosynthetic encapsulated sand columns. Geotext Geomembr 27:107-120

14. Hosseinpour I, Riccio M, Almeida MSS (2014) Numerical evolution of a granular column reinforced by geosynthetics using encasement and laminated disks. Geotext Geomembr 42:363-373 
15. Zhang L, Zhao M (2015) Deformation analysis of geotextileencased stone columns. ASCE Int J Geomech 15(3):04014053

16. Mohapatra SR, Rajagopal K, Sharma J (2016) Direct shear tests on geosynthetic-encased granular columns. Geotext Geomembr 44:396-405

17. Sharma RS, Kumar BRP, Nagendra G (2004) Compressive load response of granular piles reinforced with geogrids. Can Geotech J 41(1):187-192

18. Ayadat T, Hanna AM, Hamitouche A (2008) Soil improvement by internally reinforced stone column. Ground Improv 161(2): $55-63$

19. Wu CS, Hong YS (2008) The behavior of a laminated reinforced granular column. Geotext Geomembr 26(4):302-316

20. Ali K, Shahu JT, Sharma KG (2012) Model tests on geosyntheticreinforced stone columns: a comparative study. Geosynth Int 19(4):292-305

21. Pulko B, Majes B, Logar J (2011) Geosynthetic-encased stone columns: analytical calculation model. Geotext Geomembr 29(1):29-39

22. Zhang Y, Chan D, Wang Y (2012) Consolidation of composite foundation improved by geosynthetic-encased stone columns. Geotext Geomembr 32:10-17

23. Chen JF, Li LY, Xue JF, Feng SZ (2015) Failure mechanism of geosynthetic encased stone columns in soft soils under embankment. Geotext Geomembr 43(5):424-431

24. Almeida M, Hosseinpour I, Ricci M, Alexiew D (2014) Behavior of geotextile-encased granular columns supporting test embankment on soft deposit. J Geotech Geoenviron Eng ASCE 141: 04014116

25. Alexiew D, Brokemper D, Lothspeich S (2005) Geotextile encased columns (GEC): load capacity, geotextile selection and pre-design graphs. Contemporary issues in foundation engineering, Geotechnical Special Publication No. 131, ASCE, Reston, pp $1-14$

26. Alexiew D, Moormann C, Jud H (2009) Foundation of a coal/coke stockyard on soft soil with geotextile encased columns and horizontal reinforcement. In: Proceedings of the 17th international conference on soil mechanics and geotechnical engineering, STM Publishing House, Oxford, pp 2236-2239

27. Yoo C, Lee D (2012) Performance of geogrid-encased stone columns in soft ground: full-scale load tests. Geosynth Int 19(6): 480-490
28. Shivashankar R, Babu MRD, Nayak S, Manjunath R (2010) Stone columns with vertical circumferential nails: laboratory model study. Geotech Geol Eng 28(4):695-706

29. Kumar SG, Robinson RG, Rajagopal K (2014) Improvement of soft clays by combined vacuum consolidation and geosynthetic encased stone columns. Indian Geotech J 44(1):59-67

30. Barksdale RD, Bachus RC (1983) Design and construction of stone columns. Federal Highway Administration RD, 83/026

31. Ambily AP, Gandhi SR (2007) Behavior of stone columns based on experimental and FEM analysis. J Geotech Geoenviron Eng ASCE 133(4):405-415

32. Bachus RC, Barksdale RD (1984) Vertical and lateral behaviour of model stone columns. In: Proceedings of the international conference on in situ soil and rock reinforcement, pp 99-104

33. Shivashankar R, Babu MRD, Nayak S, Rajathkumar V (2011) Experimental studies on behaviour of stone columns in layered soils. Geotech Geol Eng 29:749-757

34. Mohanty P, Samanta M (2015) Experimental and numerical studies on response of the stone column in layered soil. Int $\mathbf{J}$ Geosynth Ground Eng 1:1-14

35. Ranjan G (1989) Ground treated with granular piles and its response under load. Indian Geotech J 19(1):1-86

36. IS: 15284 (part 1) (2003) Indian standard code of practice for design and construction for ground improvement-guidelines. Indian Standards Institution, New Delhi

37. Iai S (1989) Similitude for shaking table tests on soil-structure fluid models in $1 \mathrm{~g}$ gravitational field. Soils Found 29(1):105-118

38. IS: 1498 (2000) Classification and identification of soils for general engineering purposes. Indian Standards Institution, New Delhi

39. ASTM D4595 (1986) Standard test method for tensile properties of geotextiles by the wide-width strip method. ASTM International, West Conshohocken

40. Black JA, Sivakumar V, Bell A (2011) The settlement performance of stone column foundations. Geotechnique 61(11):909-922

41. Basu (2009) Behaviour of sand-fibre mixed granular piles. Ph.d Thesis, Indian Institute of Technology Roorkee, Roorkee

42. Ng KS, Tan SA (2015) Stress transfer mechanism in 2D and 3D unit cell models for stone column improved ground. Int J Geosynth Ground Eng 1:1-9

43. Bowles JE (1997) Foundation analysis and design. Mc Graw Hill International Editions, Singapore 